DOI https://doi.org/10.30525/978-9934-26-039-1-29

\title{
ЕКЗИСТЕНЦІЯ ЛЮБОВІ У ПОЕТИЧНІЙ ТВОРЧОСТІ ВОЛОДИМИРА ШИНКАРУКА
}

\author{
Павлова А. К. \\ кандидат філологічних наук, доцент, \\ доцент кафедри журналістики, украӥнської словесності та культури \\ Університету державної фіскальної служби Украӥни \\ Калита О. П. \\ кандидат педагогічних наук, доцент, \\ доцент кафедри журналістики, украӥнської словесності та культури \\ Університету державної фіскальної служби Украӥни \\ м. Ірпінь, Київська область, Украӥна
}

В.Ф. Шинарук - відомий український поет, композитор, режисер, бард-виконавець, педагог, член спілки письменників України. Володимир Федорович - яскравий представник житомирської поетичної школи - родом із Ружинського району на Житомирщині. Славетний вихованець Житомирського державного університету ім. І. Франка пройшов шлях від асистента кафедри до професора цього навчального закладу. Працював також певний час у Київському Національному університеті культури та мистецтв [2].

3-посеред літературних здобутків автора - поетичні збірки: «Moderato синіх сутінків» (1994), «На відстані ночі» (1996), «Перелітні дощі» (1999), «Перехрестя розлук» (2004), «Колискова для осені» (2009), «У затінку сонця»; збірки прози: «Оповідання» (2003), «Нестандартний підхід» (2006), роман «Тренер» (2011); збірка поезії та прози «На два життя одразу» (2010).

В. Шинкарук - лауреат численних музичних фестивалів, лауреат Всеукраїнської премії імені Івана Огієнка (2008); лауреат Національної програми «Мистецький олімп України» (Київ, 2009); володар першої премії в номінації «Пісенні тексти про кохання» $\mathrm{X}$ Всеукраїнського літературного конкурсу «Коронація слова»; переможець обласного літературного конкурсу «Книга року» в номінації «Проза» (книга «На да життя одразу», 2010). Серед державних нагород письменника - почесне звання «Заслужений працівник культури України» (1991), орден «За заслуги» III ст. (2009). 
Як почесному громадянину міста Житомира 19 серпня 2020 року В. Шинкаруку встановлено меморіальну дошку на будівлі Житомирського державного університету імені Івана Франка.

Особливості багатогранної творчості поета, прозаїка, співака й композитора з'ясовували А. Артемчук, Л. Данчук, Ф. Дерев'янко, Л. Красновська, Н. Миколаєнко, Л. Монастирецький тощо.

Відомий український психолог О. Музика присвятив В. Шинкаруку розділ книги «Мистецький олімп України». У праці «Психобіографічні студії з Володимиром Шинкаруком», моделюючи психологічний портрет митця, О. Музика констатує: «Мистецька позиція Шинкарука грунтується на презумпції розумності його читачів, за якими визнається право на власні висновки. Дотична до цього й «природність, органічність», але вона орієнтована вже на глядача чи слухача, оскільки розкриває ще одну грань таланту Шинкарука - талант актора, ведучого, аніматора у високому розумінні цього слова (від лат. anima - душа) людини, яка, як ніхто, вміє творити свято своєю режисерською дією й майстерною акторською грою. А те, що ми більше звикли до буднів і не завжди спроможні поцінувати його зусилля, його не обходить - він захищений вивіреним життям моральнісним імперативом: «Твори добро, хоча й будеш за нього покараний» [3].

У поетичній творчості $\quad$ В. Шинкарука яскраво оприявняюється концепція любові, феномен переживання, сутність буття через дилему іманентного i трансцендентного. Ліриці видатного представника житомирської поетичної школи притаманні особлива поліфонія, свіжі мотиви, стилістична інноваційність.

Важливу роль у поезії Володимира Федоровича відіграла насамперед онтологічна та екзистенційна проблематика в аспекті осмислення дилеми життя - смерть, свободи - необхідності, адже життя - це і є, власне, переживання людиною власного існування. Магістральною темою постає любов як вимір Всесвіту. Поет почуває себе щасливим: дароване Богом почуття взаємне, йому належить аж дві любові, і він немовби проживає обидва життя одночасно, насолоджуючись прекрасним неповторним світом: Шукаю змісту / і в житті, і в слові, / Вечірня сходить у душі зоря... / Мене окрилили одразу дві любові - / Любов моя / і любов твоя [1].

У багатьох творах письменника простежується рецепція тези Платона: «У кожній людині $€$ сонце, тільки дайте йому світити», виокремлюється платонівська ідея впізнавання душ, адже любов панує над простором і часом, вона вчить осмислювати й переосмислювати власні помилки, забувати гіркоту образ, підійматися після поразок i 
невдач [5]. Ця душевна робота допомагає в пошуках гармонії, адже, знайшовши любов, можна пізнати сутність гармонії світу. Переживаючи два життя, поет стверджує, що й старіє він «на два життя одразу - / На життя своє / і на життя твоє...» [1].

Любов не вгасає в серці ліричного героя й з роками: «Мені ще сняться щасливі сни, / В душі сміється / сонячна струна [1]. Почуття любові часто порівнюється В. Шинкаруком зі світлом, причому це світло величне, яскраве, воно здатне змінювати людину й усе довкола: Тихо ввійшла, / всміхнулась привітно, / Закутана в пахощі / сонця $\mathrm{i}$ м'яти, / Якщо в моїм домі / не стане світла, / Знатиму: / ти перестала / всміхатись [1].

У цих роздумах можна віднайти рецепцію Новозавітної концепції любові: «4. Любов довготерпить, любов милосердствує, не заздрить, любов не величається, не надимається, 5. не поводиться нечемно, не шукає тільки свого, не рветься до гніву, не думає лихого, 6. не радіє 3 неправди, але тішиться правдою, 7. усе зносить, вірить у все, сподівається всього, усе терпить! 8. Ніколи любов не перестає! Хоч пророцтва й існують, та припиняться, хоч мови існують, замовкнуть, хоч існує знання, та скасується» [4].

У поезії «Дім для душі» (За О. Ігамбердиєвим) лірик подає шлях пошуку щастя у формі чарівної казки: він прагне побудувати таку оселю, у яку щаслива душа зайшла б і назавжди залишилася б у ній жити. Він будував дім спочатку «з каменю і скла», потім «зводив кришталевий дім», навіть «будував із золота дім»: Стільки стратив днів, / врешті зрозумів... / Збудував 3 любові свій дім. Ось тоді душа / в дім мій увійшла / I навік зосталась у нім... [1]. Автор підтверджує думку про те, що любов - це вимір Усесвіту, у ній - справжній сенс людського життя, саме через любов іманентне наближується до трансцендентного.

Американський поет Д. Гілберт в одному 3 віршів зображує мандрівку любові до серця, адже серце - найважливіший орган в організмі людині. Таким чином, любов має надзвичайно важливе значення. I, на думку поета, якщо без любові й можна прожити, то таке життя виявиться неповноцінним, бідним [6].

Отже, у поетичній творчості В. Шинкарука любов - це дивовижна енергія, без якої неможливо знайти i, власне, створити щастя, однак це почуття може приносити й розчарування, біль. У багатьох віршах причини душевного болю залишаються «поза кадром»: вони подані через рецепцію ліричного героя, який дивиться з гіркотою на все суще через «темно-сірий екран вікна». Його страждання подано через описи змін у 
природі, адже тоді увесь світ довкола змінюється: Миють землю холодні роси. / Де учора була весна, / Там сьогодні - осінь [1].

Поет подає миттєвості переживань як сповідь, наповнену амбівалентністю. Він усамітнюється, переосмислює минуле, п’є «печалі свої до дна», але зрештою переконується, що не може жити без цієї любові: Може, завтра - / швидка течія / Понесе мене в темінь / останньої ночі, / І закотиться зірка моя / У знайомі до болю / заплакані очі [1].

Поряд із тим у поетичному доробку автора $\epsilon$ вірші, в яких любов постає таємничим психологічним феноменом, який в усі часи хвилював людину. Такі тексти породжують складний асоціативний зміст. Автор прагне захистити кохану від усякого зла світового, адже в коханні він бере відповідальність на себе за все, що коїться з обраницею: Якщо доля тебе / повінчає з бідою, / Якщо біль твій тебе / відпустити не схоче, / Я знайду джерело / із живою водою, / Вмию душу твою / і натомлені очі. Митець із захопленням промовляє: Я тобі намалюю / тепле / сонячне світло / І завішу ним вікна / у нашій кімнаті [1].

Любов у поезії В. Шинкарука постає справжнім виміром Усесвіту: вона зачаровує, оновлює, одухотворює, підіймає над буденністю, вчить забувати образи, будувати «дім для душі». Ліричний герой прагне захищати кохану від усяких страждань і бід, він стає багатшим на дві любові, переживає й старіє за двох. У творчості цього письменника любов оприявнюється не лише як категорія прекрасного, а ще як як категорія величного.

\section{Література:}

1. Клуб поезії. Володимир Шинкарук. URL: http:// www.poetryclub.com.ua/author.php?id=13703

2. Монастирецький Л. Шинкарук Володимир Федорович. Видатні педагоги Житомирщини. Житомир: Полісся, 2003. С. 663 - 664.

3. Музика О. Психобіографічні студії з Володимиром Шинкаруком. Волинь - Житомирщина, 2009. № 19. С. 256-273.

4. 1-ше послання Коринфянам. 13: 4 - 8. Украӥнська Біблія онлайн. URL: http://ukrbible.at.ua/

5. Прокопенко В. Благо та інші ідеї Платона. Вісник Харківського національного університету імені В.Н. Каразіна. Серія «Філософія. Філософські перипетії», 2018 (59), С. 6-15.

6. The Best Loved Poems of the American People / Ed. H. Felleman. New York: Doubleday, 2013. 896 p. 